This item was submitted to Loughborough's Research Repository by the author.

Items in Figshare are protected by copyright, with all rights reserved, unless otherwise indicated.

\title{
Long-term orientation and international joint venture strategies in modern
} \section{China}

PLEASE CITE THE PUBLISHED VERSION

http://dx.doi.org/10.1016/j.ibusrev.2009.12.005

PUBLISHER

(C) Elsevier

VERSION

AM (Accepted Manuscript)

LICENCE

CC BY-NC-ND 4.0

REPOSITORY RECORD

Buck, Trevor, Xiaohui Liu, and Ursula F. Ott. 2019. "Long-term Orientation and International Joint Venture Strategies in Modern China”. figshare. https://hdl.handle.net/2134/15165. 
This item was submitted to Loughborough's Institutional Repository (https://dspace.lboro.ac.uk/) by the author and is made available under the following Creative Commons Licence conditions.

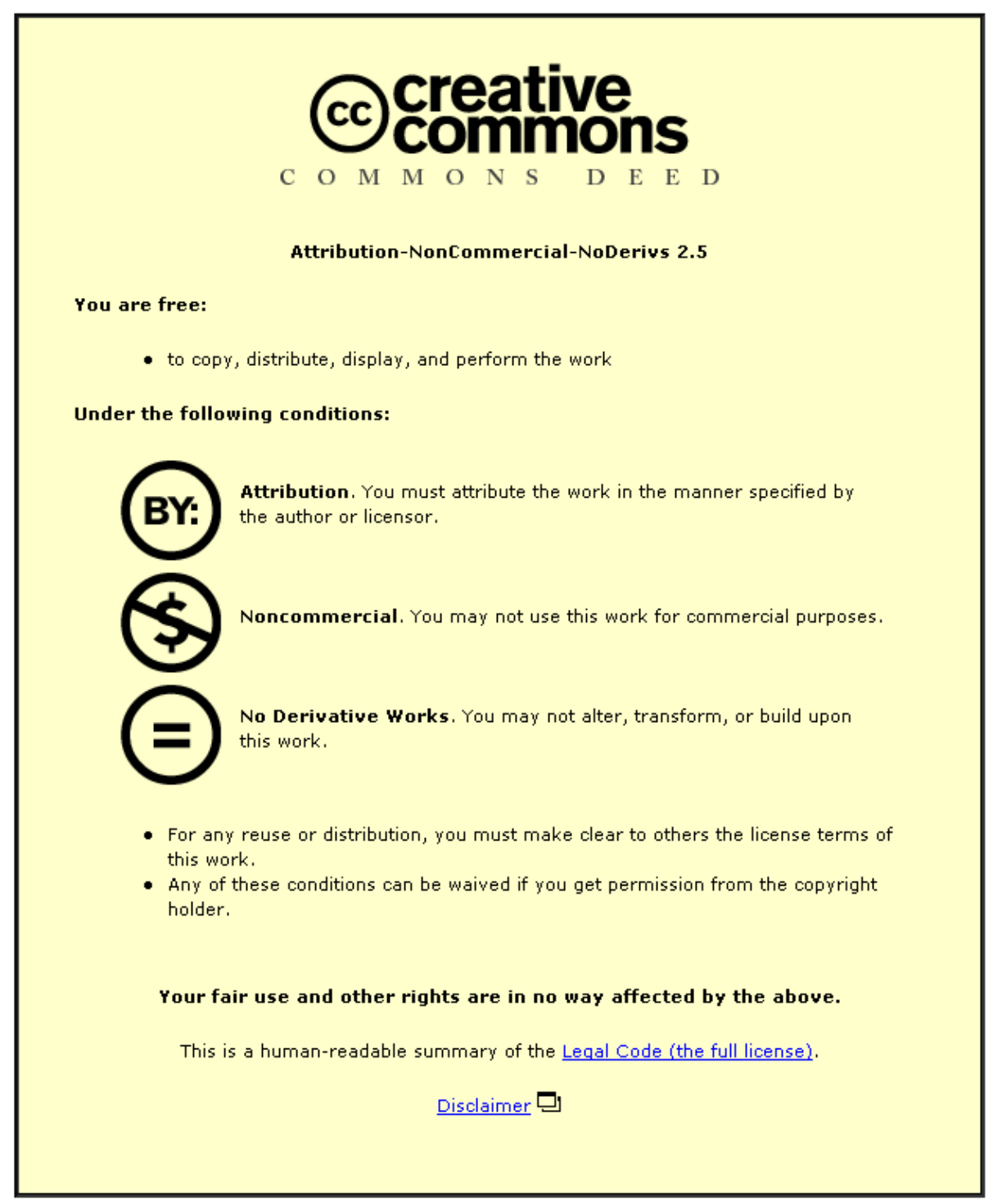

For the full text of this licence, please go to: http://creativecommons.org/licenses/by-nc-nd/2.5/ 


\title{
Long - term Orientation and International Joint Venture Strategies in Modern China
}

\begin{abstract}
Does high long-term orientation (LTO) as a distinctive feature of Chinese and Asian national culture still influence modern business decisions? It is difficult to answer this question when any such cultural impact must be qualified by the influence of local Chinese institutions. We study, therefore, different nationalities of international joint ventures (IJVs) within the same institutional setting of China. With foreign partners distanced from their national institutions, this isolates any cultural influence on strategies. We report that strategic commitment does indeed seem to be higher in IJVs with overseas Chinese and other Asian partners, but this conclusion is not general, and is limited to the subset of human resource strategies.
\end{abstract}

KEY WORDS: LONG-TERM ORIENTATION; STRATEGIC COMMITMENT; NATIONAL CULTURE; NATIONAL INSTITUTIONS; INTERNATIONAL JOINT VENTURES; CHINA 


\section{Long - term Orientation and International Joint Venture Strategies in Modern China}

It has been argued that globalization involves the gradual convergence of institutions, levels of economic development, and national cultures (Magnusson et al., 2008), and studies of cultural differences and convergence have focused on either perceived values or reported practices, as in the GLOBE research programme (Javidan and House, 2002). Cultural differences have indeed been seen to converge with material prosperity, but local institutions may limit the rate of convergence (Pothukuchi et al., 2002). Despite this general result, some cultural differences may widen (Javidan and House, 2002).

Within this global context, Chinese national culture has been widely studied, but analysis has been complicated by simultaneous cultural influence, institutional change (e.g. economic reform) and rapid GDP growth. Nevertheless, Ralston et al. (1999) found that modern Chinese work values have converged, but reported that a new managerial class has not yet forsaken its Confucian values. These values include high long-term orientation (LTO), defined as the extent to which a national culture programmes its members to accept delayed gratification of their material, social and emotional needs (Hofstede and Bond, 1988).

This paper contributes to this debate on time orientation by taking a fresh perspective. It focuses on firms' strategies rather than surveys of attitudes, and this focus dispenses with the need to model entry choice or international joint venture (IJV) performance in the context of cultural differences (Magnusson et al., 2008). It addresses its central research 
question, do the levels of time commitment in the strategies of Chinese firms in the twenty-first century still reflect a national culture of high LTO? An answer to this question will add to our empirical understanding of cultural influence generally, and will complement the evidence collected in China by Li et al. (2008) in relation to the choice of low/high commitment employment modes.

We first position our study within the extant literature, explaining the research gap that we intend to fill. We then go on to generate hypotheses, followed by the usual sections on Results, Discussion and Conclusions.

\section{Long-Term Orientation and Institutions}

Besides different legal, political and other institutions, business with China for westerners involves cultural distance (Tihanyi et al., 2005), and Cross-Cultural Psychology has tried to pin down these different national characteristics by conducting attitudinal surveys. They have revealed significant inter-country differences. For example, Hofstede (2007) reported measures for the USA (with China in parentheses) of power/distance tolerance (PDT) at 40(80), masculinity 62(66), individualism 91(20), and uncertainty avoidance 46(40). Thus, relatively low individualism and high levels of PDT are distinctive features of Chinese culture compared with the USA.

In addition to these four familiar cultural dimensions, however, Hofstede and Bond (1988) tailored a fifth element specifically for the Asian business environment: Confucian 
values that included LTO, defined above. High LTO turned out to be a third distinctive feature of Chinese culture, with the USA's LTO measured to be 29, and China's 118. LTO is arguably the most important cultural dimension through its strong association with a nation's propensity to save, invest, and thus per capita income growth (Hofstede, 2003); indeed, Hofstede (2001) observes that (p 351) “...long-term orientation is thus identified as a major explanation of the explosive growth of the East Asian economies in the latter part of the $20^{\text {th }}$ century." We therefore focus on LTO as a potentially important influence on firm strategies in China compared with the rest of the world.

However, the validity of Hofstede's concept of LTO is not universally accepted, and a number of alternative time-oriented constructs are available. One of the first researchers in Cross-Cultural Psychology was Hall (1959), who focused on the tendency for individuals and organisations in a country to treat time in a "monochronic" or "polychronic" way. Monochronic societies tended to address one task at a time in a sequential manner, and this was considered to be a familiar western approach to time, with careful planning and scheduling. Polychronic societies, however, are able multi-task and are more concerned with human interaction than particular outcomes. These ideas were adapted by Trompenaars and Hampden-Turner (1997), whose concept of HumanTime Relationship introduced sequential (monochronic) and synchronic (polychronic) relations with time, adding the notion of past, present and future-oriented societies. However, concepts turned full circle with the GLOBE project's concept of future orientation, which turned out to be very close to Hofstede's LTO, as the degree to which a collectivity encourages and rewards future-oriented behaviors such as planning and delaying gratification (Javidan and House, 2002). Similarly, Harris and Carr (2008) have 
considered time orientation in terms of the timeframes within which managers intend to achieve their goals.

Despite these nuanced differences, however, different empirical measures of time orientation across countries have produced fairly stable results in broad terms (Harris and Carr, 2008). Hofstede and Trompenaars (1997) clearly identify strong short-term HumanTime relations in the USA and UK and strong long-termism in Asian societies, albeit with countries like the Netherlands reporting contradictory results. However, in four international case-studies Harris and Carr (2008) found little correlation between declared business purposes and the national time-orientation measures of Hofstede and Trompenaars. For example, Harris and Carr (2008: 109) find an American firm with 15year strategic objectives

Taking certain contradictions into account, this study feels confident in recognising broad clusters of nations revealed by the GLOBE project in relation to time orientation (Javidan and House, 2002). For example, the USA and UK cluster exhibits short-termism, whereas there is high LTO in most Asian countries. In contrast with the attitudinal surveys of cross-cultural psychology (Hofstede, 2001; Trompenaars and Hampden-Turner, 1997) and deep case analysis of perceived business objectives in relation to time (Harris and Carr, 2008), we follow the GLOBE project (Javidan and House, 2002) and investigate the actual business practices of IJVs in China. For example, rather than enquire about the attitudes of HR managers, we focus on whether firms adopt a hire-and-fire approach to employee hirings, whether they invest in long-term training and whether they invest in arrangements such as employee pensions that cover long time periods. Without implying 
criticism of other approaches, our focus is on what firms do as opposed to what they believe.

While our cross-sectional study abstracted from institutional change, national institutions remain as an important potential influence, besides national culture. However, it will be argued that a cross-sectional study across different nationalities of partner absented from their home institutions means that all observations are made in the context of Chinese institutions, and variations in levels of strategic commitment may be attributed to culture.

Institutionalists (e.g. Peng, 2002) downplay intangible values, beliefs, attitudes and norms (i.e. national cultures) as influences on firms' decisions, but instead emphasize formal, tangible institutional structures that are consciously designed by humans. They feel uncomfortable with Cross-Cultural Psychology, which may be seen as national stereotyping (Adler, 2002), and relegate national cultures to the status of mere "informal" institutions that influence the shape of formal, deeply embedded institutions (North, 1990; Hill, 1995). One advantage of considering both institutions and culture as useful concepts is that an important difference between them can be exploited: mental attitudes (culture) are carried along as baggage when a human migrates internationally but physical institutions must be left behind. This study makes use of this distinction.

In addition to the finding of Ralston et al., (1999) that younger Chinese managers have given different levels of importance to cultural values, Cowen (2002) reports how globalization may be destroying the international diversity of national cultures. Leung et 
al. (2005: 367) claim that “...cultural changes are more frequent than previously assumed”, advocating (366) “...a dynamic view of culture”. Finally, as noted above, Tang and Koveos (2008) note that each of Hofstede’s cultural dimensions is converging over time with income growth, though institutions can hold back this curvilinear relation. Perhaps this institutional resistance has been responsible for LTO in China and the rest of Asia remaining high.

Whether "mental programs", i.e. national cultural dimensions, are stable or subject to change is clearly an empirical question that can be addressed by repeated attitudinal surveys, though these surveys have not so far yielded resolution after forty years of tests (Triandis, 2004). To repeat, rather than running even more attitudinal surveys or producing yet more lists of revised cultural dimensions, this paper focuses on practices not values (Javidan and House, 2002; Maseland and van Hoorn, 2009), and specifically on a range of firm strategies, borrowing the notion of strategic commitment from the entry mode literature (Pedersen and Petersen, 1998).

It is argued that if stable cultural elements, and specifically high LTO, continue to be an important force in Asia and modern China, as predicted by Hofstede, this will be reflected in firms' strategic decisions, mediated to some extent by organizational culture (Sirmon and Lane, 2004). IJVs constitute a useful laboratory for addressing our research question. First, IJVs represent a recent, dynamic phenomenon, and should therefore present a strong test for Cross-Cultural Psychology's assumption of cultural stability. 
Second, the nationality of IJV partners enables us to control for national institutional influence.

\section{LTO and Firm Strategies in China}

Our paper focuses on the single dimension of culture that was introduced by Hofstede and Bond (1988) to accommodate a distinctively Asian phenomenon. This LTO dimension is related to Confucian values that have an impact on family relationships, work relationships, governmental relationships and trust-building. Creating and maintaining long-term, trusting relationships in China influences negotiations, decisionmaking, enterprise strategies and international relations.

Of course, Hofstede (2001: 361) argues that high LTO has a strong impact on firm behaviour: "Businesses in long-term-oriented cultures are accustomed to working toward building up strong positions in their markets; they do not expect immediate results. Managers (often family members) are allowed time and resources to make their own contributions. In short-term cultures, the 'bottom-line' (the results of the past month, quarter or year) is a major concern; control systems are focused on it and managers are constantly judged by it.” Consequently, a country’s high LTO may conceivably influence firm strategies, mediated by organisational culture.

In general terms, such time orientation has been most prominent in the strategic planning literature (Das 1991; Ramaprasad and Stone, 1992), particularly in relation to planning 
horizons and scenario planning in the long term (Schoemaker, 1993). However, this temporal dimension is also relevant to corporate strategies in general, and Schneider and Barsoux (2002: 134) provide an exhaustive taxonomy of strategies that we adapted for our purposes. They distinguish between top-tier, HQ (here, parent company)-level strategies that comprise the firm's adaptation to its external environment in general. For example, parent firms may be defenders or prospectors, and may modify the firm's boundaries through mergers, acquisitions and foreign market entry, through licensing, JVs, greenfield projects, etc.

However, these external, peak-tier strategies were not our focus in the context of small Chinese IJVs with an average of around three hundred employees in total. Instead, our focus was on internal, functional strategies (Schneider and Barsoux, 2002: 135), i.e. marketing strategies, production strategies (internal diversification, investment, costreduction and sourcing strategies), R\&D, HRM and governance strategies. In fact, investment strategy is a catch-all measure that reflects the total cost of all the firm's peak tier and functional strategies. Although some studies have already investigated the impact of dimensions of culture on single functional strategies such as internationalization (foreign market entry) or governance strategies (Brouthers, 2002; Pothukuchi et al., 2002; Salter and Niswander, 1995), this paper examines a broader range of strategies in IJVs simultaneously. In this respect, it is not concerned with culture/performance relations in IJVs (Barkema and Vermeulen, 1997) and therefore does not need to model IJV performance. Below, under Methods, we explain our choice of three strategies for 
investigation, and Table 1 explains the time dimension in relation to these strategies, with short-term/long-term examples.

Insert Table 1, near here

These strategies listed in Table 1 have all been subjected to analysis in terms of their time orientation. For example, HRM strategies have been studied (Black, 1999; Gerhart and Fang, 2005) in relation to national culture (particularly LTO) and the long term commitment in employee attitudes and management strategies. The "competing capitalisms" concept in the strategy literature (Thomas and Waring, 1999) is relevant in relation to R\&D and general investment decisions. In this literature, highly-committed, relational investors in countries like Japan are associated with higher levels of long-term investment, mainly out of retained earnings. R\&D and investment in fixed assets generally represent strategies that offer pay-back over a long gestation period compared with investment in more liquid assets, though the type of investment may be important: for example mergers and acquisitions represent expenditures that can be completed quickly and bring immediate sales growth, while organic growth through gradual internal expansion must take longer. Of course, overseas firms may be reluctant to locate R\&D in China because of weak local intellectual property protection and the likelihood of technological "spillovers" (Liu and Buck, 2007), but there is no reason to expect these fears to vary between Asian and western IJV partners. On the other hand, we are unable to distinguish between different types of $\mathrm{R} \& \mathrm{D}$, for example involving basic, long term research or the development of minor product adaptations for immediate sale (Liu and 
Buck, 2007). Again this becomes a problem only if the type of time horizon for R\&D varies consistently according to the nature of foreign ownership.

Thus, LTO may influence strategies, but the situation becomes more complicated within Chinese IJVs, where the national cultures of partners are mixed with local institutional influence. To simplify matters, it seems useful to consider "clusters" of national culture (Javidan and House, 2002). For example, investors in Chinese IJVs from Hong Kong, Taiwan, S Korea and Japan inherit a culture of high LTO, with national measures of 96, 83, 73 and 76 respectively (Hofstede, 2007), and of course Hong Kong and Taiwan have a mainly Chinese culture. However, foreigners from the USA and the EU in Chinese IJVs are from countries with relatively low LTO (29 for the USA; within the EU, ranging from 20 in the UK to 32 in Poland). We therefore allocate one cultural cluster to US and EU investors in IJVs from countries with relatively low LTO, and partners from these countries in an IJV may be expected to emphasise the short-term imperative in strategic decisions. On the other hand, IJV partners from a Chinese cluster (PRC, Hong Kong and Taiwan) and another Asian cluster (S Korea and Japan) of countries may be expected to give more priority to the long term in strategic decisions.

Rather than observe a time-related concept such as LTO by developing hypotheses in relation to changes in LTO over time and testing them with longitudinal data, we propose hypotheses that focus on the possible influence on strategies of different nationalities of JV partners, with contrasting levels of LTO. In this way, we may hypothesise and test 
whether a Chinese culture of LTO has been strong enough to withstand foreign cultural influence.

Insert Table 2, near here

This approach also allows us to contribute to the culture vs institutions debate. We follow Peng (2002) who devised an ingenious study of comparisons between the practices of American and Chinese entrepreneurs in China and America. Of course these actions must reflect the national cultural and institutions of their practitioners, but China-born entrepreneurs leave behind their Chinese institutions when they move to the USA, where decisions are made within the American institutional environment. Any "Chinese" influence on their decisions can only be cultural influence.

The first column of Table 2 shows that an IJV situated in mainland China, with local PRC ownership and management, is obviously exposed to the influence of mainland Chinese culture and institutions. Indeed, all nationalities of partner in row (2) of Table 2 may be expected to bring their cultural inheritance to bear on enterprise strategies, since mental attitudes transfer along with human migrants.

With overseas Chinese partners, however, the institutional influence from their home country cannot influence JVs in mainland China. For example, Taiwanese partners enter the PRC leaving behind their multi-party political institutions. However, some of the institutions of mainland and overseas Chinese may be similar. In the case of columns (3) and (4) of Table 2, however, partners from the west and from other Asian countries must leave their distinctive home institutions behind. The association of different nationalities 
of JV partner (with different levels of LTO) with JV strategies now enables us the opportunity to develop hypotheses and contribute to the culture vs institutions debate.

With these concepts, strategies and national clusters established, the development of hypotheses derived from Cross-Cultural Psychology across all strategies is straightforward:

H1: the presence of various long term strategies within Chinese IJVs is positively associated with the degree of management control by mainland Chinese investors, via the influence of their national culture and institutions.

As explained above, however, $\mathrm{H} 1$ fails to distinguish between cultural and institutional influence (Child and Yuan, 1996). For example, a long-term, high-commitment HRM strategy (the very antithesis of a short-term, "hire-and-fire” approach) in an IJV may be consistent with a culture of high LTO, but may also be explained by institutions, e.g. the presence of State or Party representatives on the boards of the Chinese parents of IJVs. Of course, the evolution of these representatives as an institutional feature may itself reflect a national culture of high Collectivism and PDT, but speculation on their ultimate cause is futile, according to a co-evolutionary view (Lewin et al., 2004).

Therefore, we propose that investors from Chinese communities outside the PRC (i.e. Hong Kong, Taiwan) can only influence the strategies of their IJV through their national culture, and not through their own national institutions, which they have left behind in 
their homelands. This implies H2, which isolates the impact of a Chinese culture in a way that could not be achieved by studying the impact of local Chinese ownership:

H2: the presence of various long-term strategies within Chinese IJVs is positively associated with the degree of management control by foreign investors from outside the PRC, but with a Chinese culture.

Although mainland China has a distinctive set of institutions founded on single party political rule, it could be argued (see Table 2) that there are also similarities between institutions in mainland and overseas China. As a robustness check on H2, therefore, a consideration of IJV control by non-Chinese Asians from countries with high LTO may be expected to isolate the influence of LTO, to see if it may be generalised beyond the Chinese context. Therefore, H3 addresses the cultural influence of foreign partners from other Asian countries:

H3: the presence of various long-term strategies within Chinese IJVs is positively associated with the degree of management control by foreign investors from non-Chinese Asian countries with high levels of LTO in their national culture.

While IJV management control by partners with Asian nationality may be expected to be associated positively with long term strategies (H2, H3), the control by owners from Western countries with low LTO may, in contrast, be expected to be associated with short-term strategies: 
H4: the presence of various long-term strategies in Chinese IJVs is negatively associated with the degree of management control by foreign investors from countries with low levels of LTO in their national culture.

Thus, the problems with identifying the time-orientation of foreign managers as a key cultural influence on the strategies of an IJV are less serious with foreign control, since foreign owners and managers are removed from their own home institutional contexts in a Chinese IJV. Ironically, therefore, we go to China to measure the impact of foreign cultures, distanced from their home environment. The novelty of these hypotheses is that using the data and methods described below allows us to address our central research question; do the strategies of Chinese firms in the twenty-first century still reflect a national culture of high LTO?

\section{Data and Methods}

Firm strategies are of course influenced by many firm, country and international variables, and we must hold many of them constant in order to identify the influence of LTO on strategies. We control for some institutional influences by basing our tests of H1H4 on firms using a single governance vehicle (the IJV), in a single category of high-tech firms, within a common environment of Chinese economic, social, legal and political institutions. Within these target firms, we observe variations in the degree of control by investors from mainland China together with three other groups of countries. These comprise (i) Chinese investors from Hong Kong and Taiwan, (ii) investors from other 
Asian countries with high LTO (Japan and S Korea) and (iii) investors from the West (USA and EU) characterized by low LTO.

IJVs (with controls for city location, date of establishment and size of firm) were deliberately chosen because the IJV has been the dominant mode of foreign entry in China, and within IJVs, local attitudes and beliefs are fully exposed to the influence of international partners. Of course, other dimensions of national culture, besides LTO, may influence a firm's strategies, but individualism and PDT etc cannot be expected to influence the time horizons of business strategic decisions.

To obtain data to test our four hypotheses, we conducted a postal questionnaire survey of Chinese IJVs in a single survey from December 2006 to April 2007, asking for responses relating to the period 1998-2005, since in 1998 foreign ownership shares in JVs were freed from State control. An abbreviated list of the main questions is provided in an Appendix.

We limited the sample to high-tech industries in order to control for the impact of industrial affiliation on strategic decisions across the three nationalities of IJVs, though in addition, controls for industrial sub-sectors within the high-tech sector were used. We obtained useable responses on the three strategies, with time dimensions identified in Table 1: human resource, investment and R\&D strategies. Three cities, Beijing, Tianjin and Qingdao, were surveyed due to the concentration of particular types of IJVs in these regions. Specifically, Japanese, Korean and overseas-Chinese IJVs mainly locate in the 
Pan Bohai region that includes these three cities, accounting for $67 \%$ of Korean investment and $40 \%$ of Japanese investment in China (Wang, 1998). Selecting our sample firms from the three cities enabled us to avoid the problem of the underrepresentation of Sino-Korean IJVs in other regions. According to lists obtained from Beijing, Tianjin and Qingdao Industry and Commerce Bureaus, in 2006 there were 2,126 IJVs in Beijing, 1,075 in Tianjin and 461 in Qingdao. Each of these IJVs was approached and a willingness to participate in our survey was indicated by 2,053 JIVs, together representing $56 \%$ of the IJV population in these three cities.

The survey instrument was translated from English into Mandarin Chinese and then backtranslated by three Chinese professors in Beijing, to ensure its validity. A pilot study was carried out where two workshops were organized, involving groups of 6 and 8 senior managers of three categories of Sino-foreign IJVs. They were asked to complete the questionnaire and identify ambiguous questions. We modified the questionnaire accordingly, based on the feedback received from the workshops and copies were mailed to 2,053 IJVs.

Two well qualified and experienced research assistants in Beijing were engaged through our established research partners, the Greatwall Enterprise Institute, to conduct postal questionnaire surveys during 2006. Given the issues we were exploring, a key informant approach was adopted, with the respondent being the CEO or senior manager of the surveyed IJVs. The research assistants made follow-up phone calls and visits to 105 firms. A total of 316 useable questionnaires were received (a 15\% response rate for the 
sample surveyed, but only $8.6 \%$ of the population of IJVs in the three cities) with 104 IJVs with US-EU (low LTO) partners; 103 IJVs with overseas Chinese ownership (Hong Kong and Taiwan); and 109 IJVs with other Asian co-owners (Japan and Korea). The possibility of non-response bias was checked by comparing the characteristics of the respondents with those of the population. The calculated t-statistics for the number of employees, local Chinese control and age of the firm were all statistically insignificant, indicating no significant differences between respondent and non-respondent firms.

Hypotheses were tested for each individual strategy in Table 1 in relation to management control. The number of Chinese and foreign senior managers were the main explanatory variables, with the strategic decisions measured variously by interval scales (e.g. the percentage of employees with permanent contracts and pension provisions as well as investment and R\&D strategy, see Appendix).

\section{Dependent variables.}

Our focus was on the time-orientation of various IJV strategies, and it was reported above that Schneider and Barsoux (2002) proposed a long list of candidates. From these peaklevel and functional strategies, and in the interest of a questionnaire of manageable length, we had to select representative strategies for our study. It was therefore decided to focus (see Table 1) on investment strategy (which embraces the whole range of HQ and functional strategies), $R \& D$ strategy, which comprises adaptation to the external technological environment and straddles the HQ/local interface and HRM strategy, representing a standard functional area. 
For each of these three strategic categories, we were able to identify the firm's focus on long and short term elements. For example, investments can be made in current assets, including financial assets, while other investments (e.g. in fixed assets or takeovers) reflected a longer time horizon for pay-back. For investment and R\&D strategies, it was necessary to transform absolute variables by dividing by the value of sales, to correct for the influence of firm size, since larger firms are more likely to engage in local $R \& D$, with more money to set up local R\&D laboratories. We used employee tenure, the percentage of long-term contracts and the extent of pension provision as indicators of the timeorientation of HRM strategies. The proportion of R\&D spending to total sales, and R\&D investment contributed by parent companies, were used as an indicator of R\&D strategy. This study is only interested in the JV's R\&D strategy, not its location, which is of course a bigger subject.

\section{Independent variables.}

To estimate foreign influence on the time-orientation of these IJV strategies, we used the number of foreign senior managers and Chinese senior managers on the boards of IJVs as a measure of the degree of foreign control. Three dummy variables were created for the national clusters of US-European/Chinese IJVs, Japan-Korean/Chinese IJVs, and overseas Chinese (Hong Kong-Taiwan) IJVs.

\section{Control variables.}


We controlled for firm Age in years since founding, and firm Size measured by number of employees. As the questionnaire survey was conducted in different cities, we also controlled for location by introducing two dummy variables for Tianjin and Qingdao. We also included (within high-tech) industry dummies in the estimation.

Common methods variance may be a potential problem when both dependent and independent variables are generated from the same respondents at the same time. Common methods bias was tested by performing the single factor test proposed by Podsakoff and Organ (1986). We conducted a factor analysis with all the variables used in our study and obtained a four-factor solution. The largest factor explained only $26.58 \%$ of the variance. Hence, we do not have evidence of common methods bias with our dataset.

To test our hypotheses, we estimated an Ordered Probit model for HRM strategies, as the dependent variables were measured using different intervals. For example, we asked the following question: 'what is your average employee's tenure with the firm?' followed by a choice between the categories (1) ‘<1 year’, (2) '1-3 years’, (3) ‘4-5 years’, (4) ‘6-10 years', and (5) 'over 10 years'. In addition, we also estimated the Tobit model, given that the dependent variable for the R\&D investment strategy is censored and measured by the percentages of R\&D investment in fixed assets, i.e. between 0 and 1 .

\section{Results}


The descriptive statistics for the variables used in the analysis and the matrix of correlation are presented in Table 3, and show the average age (8.5 years) and size of firms (300 employees) in our sample. Local Chinese investors, on average, account for 44\% of IJV ownership across different types of IJVs. The average numbers of senior Chinese and foreign managers (of different nationalities) in each IJV are five and three. In our tests, categories of enterprise strategy are addressed in turn, to identify any variations in time-orientation due to LTO. The three dummy variables for three types of IJVs enter the estimating equation separately in order to avoid possible multi-collinearity and differentiate the impact of different cultural clusters on firm strategies.

Insert Table 3 near here

Table 4 reports the results from the formal tests on the determinants of HRM strategy, with three categories comprising job tenure, long-term contracts and pension provision. They show that the number of mainland Chinese senior managers in IJVs has a positive association with long-term HRM strategies. In particular, Chinese management control (the number of local Chinese senior managers on the board) has a significant, positive association with pension provision. These results are in line with H1, but do of course not distinguish between institutional influence and the impact of the cultural phenomenon of LTO on HRM strategies.

Insert Table 4 near here 
However, the dummy variable for control by overseas Chinese (from Hong Kong and Taiwan) is statistically significant, and this applies consistently across the three observed dimensions of HRM strategies. This result supports $\mathrm{H} 2$ and indicates that Chinese overseas investors, distanced from their home institutions, but sharing a Chinese culture (with high levels of LTO) tend to adopt long-term HRM strategies.

Of course, these conclusions may be questioned if there are similarities between the institutions of mainland and overseas Chinese. Nevertheless, the result of the dummy variable for Japanese-Korean control of Chinese IJVs is positively significant at the $10 \%$ significance level, suggesting Japanese and Korean investors with high levels of LTO are also likely to adopt long-term HRM strategies. Thus, H3 is weakly supported.

In contrast, the results suggest that the number of US and European senior managers in US-European/Chinese IJVs has a negative association with long-term HRM strategies, as hypothesised in $\mathrm{H} 4$, indicating that foreign senior managers from countries with a national culture of low LTO are not willing to provide secure employee tenure, long-term contracts and pensions in Chinese IJVs. This result supports $\mathrm{H} 4$ in relation to HRM strategy.

Taken together, we report quite consistent evidence which suggests a link between HRM strategies and management control by investors from countries with different levels of LTO, as hypothesized in H1-4.

Insert Table 5 near here 
The results for investment strategies are presented in Table 5, and it can been seen that there is again a positive link between management control by local Chinese investors and long-term investment in fixed assets in Chinese IJVs, as proposed in H1. The dummy variable for Chinese IJVs with Chinese overseas investors also has the correct sign and is significant, thus supporting H2. However, the other two dummy variables for US-EU control of Chinese IJVs, and Japan-Korea control are not statistically significant. Hence, the results for investment strategies are not consistent with $\mathrm{H} 3$ and H4: control by local Chinese is associated with long-term strategies (H1), but we cannot confirm whether this is an institutional effect or the effect of the LTO of local Chinese managers.

Insert Table 6 near here

The results for (long-term) $R \& D$ strategies summarised in Table 6 show a similar pattern to investment strategies. Management control by local Chinese investors positively affects long-term R\&D strategy. This explanatory variable is also statistically significant for R\&D investment contributed by parent companies. Thus, the result is in line with H1. $\mathrm{H} 2$ is supported in terms of long-term R\&D spending, given that the dummy variable of China/Hong Kong-Taiwan IJVs is positively significant, implying that overseas Chinese investors are more willing to invest in R\&D. However, the dummy variable for China/Japan-Korean IJVs is again insignificant. Thus, H3 is not supported. Management control by investors from countries with low levels of LTO is also insignificant.

In terms of firms' own characteristics, the results show a positive and significant association between age, size and HRM strategies, suggesting that IJVs with a long history and large size are more likely to adopt long-term HRM strategies, perhaps 
because large, older firms have the resources to invest in pensions, etc. The variable for size also has a positive impact on investment and R\&D strategy, despite the fact that the investment and R\&D variables are represented as a proportion of sales, thus correcting for size. This result indicates that large firms are able to achieve the economies of scale that justify investment in R\&D laboratories.

Discussion and Conclusion

Using firm-level primary survey data, this study first establishes that the degree of control by local Chinese partners in IJVs is associated with greater LTO across three groups of strategies, but this may be attributed to the effects of a culture of high LTO and/or local institutional influence. This result has strong implications for foreign managers. Despite references to a younger generation of Chinese managers (Ralston et al., 1999), the evidence points towards Chinese partners with consistently longer time horizons across a range of strategies. Whether attributable to national culture, institutions or both, such cultural distance still needs to be addressed and resolved, possibly with cultural sensitivity training for foreign expatriates.

In relation to partners from beyond the PRC, however, our study also estimates the separate impact of national culture on enterprise strategies in Chinese IJVs by controlling for national institutional influence. With different nationalities of IJV partners, (i.e. USEU, Japan-Korea and Chinese overseas investors (from Hong Kong and Taiwan), we established a link between levels of LTO in the home countries of investors and managers 
and the strategic decisions taken by Chinese IJVs, offering a better understanding of the impact of national cultures on enterprise strategies in IJVs. We therefore fill a gap in the literature: our results suggest that LTO has survived as a stable and influential feature of Asian societies, and western partners continue to exert a short-termist influence. They also suggest that western foreign partners can expect to find a degree of cultural distance with local Chinese partners, though partners from other Asian countries may feel more comfortable culturally.

However, the relation between strategies and LTO is not uniform. In relation to HRM strategy, we find the strongest support for the notion that management control by nationalities with high LTO continues to affect Chinese IJV strategies in China. Firstly, management control by local mainland Chinese investors is associated with long-term HRM strategies. Secondly, these results are replicated for the degree of control from countries with overseas Chinese and for non-Chinese Asian countries with high LTO, consistent with the cultural explanation of long term strategies. Third, the degree control by western investors mirrors this conclusion, with its negative relation with long term strategies. Each of the four proposed hypotheses is supported in relation to HRM strategies. This finding suggests the continued cultural influence of high LTO in relation to HRM in modern China, even though transition from a central planned economy to a market economy has taken place.

In contrast, the results for investment and R\&D strategies uniformly provide little support for our hypotheses, implying that some cultural convergence has occurred through 
globalization, though it should be remembered that our IJV sample was deliberately chosen to favour such a conclusion.

Explanations for this pattern of results may be suggested. For example, HRM decisions in relation to employees' contracts (e.g. pension provisions and length of contract) have a direct impact on employees and reflect how employees are treated in IJVs. Decisions of this kind which involve social interaction between employees and senior managers may provide more opportunities for cultural influence. On the other hand, decisions concerning long term investments in fixed assets and R\&D are inanimate, offering little role for cultural influence. Alternatively expatriate managers may be prepared to leave HRM practices to mainland Chinese managers, providing a channel for the influence of their high LTO and institutional environment (Leung and Kwong, 2003).

Reflecting on the research questions posed in the Introduction to this paper, our results suggest, even in modern China, that high LTO and strategic time-horizons seem likely to represent an ongoing source of cultural distance, but only in relation to HRM strategies, supporting Li et al. (2008). With other, more impersonal strategies, globalization may have achieved cultural convergence. In this restricted sense, Hofstede's cultural stability hypothesis survives only in relation to HRM. To this extent, however, Cross-Cultural Psychology would appear to survive as a useful theoretical lens.

Finally, the findings from the study may inform business decisions relating to different strategies. Expatriates in Chinese IJVs may still have to accept the local influence of high 
LTO on strategies, if they continue to leave HRM decisions to culturally-distant local managers. The HRM strategies of IJVs need to reflect LTO in order to attract and retain local employees. Other strategies are also affected in the same way by the number of local Chinese managers on an IJV, but in this case it is not possible to distinguish the impact of culture and institutions separately. In contrast with HRM, investment and R\&D strategies seem to be unaffected by the presence of an Asian or Western investor, and the message seems to be (globalized) "business as usual”.

Our study has limitations. First, apart from national culture, the global/multidomestic/transnational strategies (Harzing, 2000) of partners to an IJV may be expected to influence local strategic decisions with an element of time orientation, e.g. R\&D location. However, we are unable to address associations between these strategies and the commitment level in IJVs in our cross-sectional study. Future studies should examine whether certain nationalities of foreign partners were associated with particular internationalisation strategies ${ }^{1}$. Second, our study mainly focuses on the stability of national culture, specifically LTO. Hence, it cannot identify the impact on levels of strategic commitment from other elements of national culture besides LTO. Future studies should account for interaction between other cultural elements and LTO. For example, LTO may be associated with high collectivism or even Self Transcendence (Meulemann, 2009), since the interests of future generations are collectively taken into consideration where LTO is high.

\footnotetext{
${ }^{1}$ We would like to thank an anonymous reviewer for this constructive suggestion.
} 
Third, we address the relationship between LTO and enterprise strategies using a crosssectional analysis, estimating the cultural influence of LTO through the nationality of JV partners. In future studies, insightful findings can be drawn by conducting a longitudinal data analysis or collecting deep case studies to capture the dynamic dimension of LTO.

\section{ACKNOWLEDGEMENT}

We would like to thank the Leverhulme Trust for their financial support of this project, grant F/00 261/U.

\section{References}

Adler, N. (2002) International Dimensions of Organizational Behavior. Cincinatti OH: Southwestern Press.

Barkema, H.G. and Vermeulen, G.A.M. (1997) What Differences in the Cultural Backgrounds of Partners are Detrimental for International Joint Ventures? Journal of International Business Studies, 28/5, 845-864.

Black, B. (1999) National Culture and High Commitment Management, Employee Relations, 21/4, 389-404.

Brouthers, K.D. (2002) Institutional, Cultural and Transaction Cost Influences on Entry Mode Choice and Performance, Journal of International Business Studies 33/3, 203-221.

Child, J. and Yuan, L. (1996) Institutional Constraints on Economic Reform: the Case of Investment Decisions in China, Organization Science, 7/1, 60-77.

Cowen, T. (2002) Creative Destruction: How Globalization is Changing the World's Cultures. Princeton, NJ: Princeton University Press.

Das, D.K. (1991) Time: The Hidden Dimension in Strategic Planning, Long Range Planning, 24/3, 49-57.

Gerhart, B. and Fang, F. (2005) National Culture and Human Resource Management: Assumptions and Evidence, International Journal of Human Resource Management, 16/ 6, 971-986. 
Harris, S. and Carr, C. (2008) National Cultural Values and the Purpose of Businesses, International Business Review, 17/1, 103-117.

Harzing, A.-W. 2000 101-120 An Empirical Analysis and Extension of the Bartlett and Ghoshal Typology of Multinational Companies, Journal of International Business Studies, 31/1, 101-120.

Hill, C.W.L. (1995) National Institutional Structures, Transaction Cost Economizing and Competitive Advantage: The Case of Japan, Organization Science, 6/1, 119-131.

Hofstede, G. and Bond, M.H. (1988) The Confucian Connection: From Cultural Roots to Economic Growth. Organizational Dynamics, 16/4, 4-21.

Hofstede, G. (2001) Culture's Consequences, Comparing Values, Behaviors, Institutions, and Organizations across Nations, London: Sage Publications.

Hofstede, G. (2007) www.geert-hofstede.com. (accessed 24 Nov 2008)

Javidan, M. and House, R.J. (2002) Leadership and Culture Around the World: Findings from GLOBE, Journal of World Business, 37/1, 1-2.

Leung, K., Bhagat, R., Buchan, N.R., Erez, M. and Gibson, C.B. (2005) Culture and International Business: Recent Advances and their Implications for Future Research, Journal of International Business Studies, 36/4, 357-378.

Leung, K. and Kwong, J. (2003) Human Resource Management Practices in International Joint Ventures in Mainland China: A Justice Analysis, Human Resource Management Review , 13/1, 85-105.

Lewin, A.Y., Kim, J. and Weigelt, C. (2004) The Nation-State and Culture as Influences on Organizational Change and Innovation, in M.S. Poole and A.H. Van de Ven (eds.), Handbook of Organizational Change and Development. Oxford: Oxford University Press, 324-353.

Li, J, Lam, K., Sun, J.J.M. and Liu, S.X.Y. (2008) Strategic Human Resource Management, Institutionalization, and Employment Modes: An Empirical Study of China, Strategic Management Journal, 29/3, 337-342.

Liu, X. and Buck, T. (2007) Innovation Performance and Channels for International Technology Spillovers: Evidence from Chinese High-Tech Industries, Research Policy, 36/3, 355-366.

Magnusson, P., Baack, D.W., Zdravkovic, S., Staub, K.M. and Amine, L.S. (2008) MetaAnalysis of Cultural Differences: Another Slice at the Apple, International Business Review, 17/5, 520-532. 
Maseland, R and van Hoor, A. (2009) Explaining the Negative Correlation between Values and Practices: A Note on the Hofstede-GLOBE Debate, Journal of International Business Studies, forthcoming.

Meulemann, H. (2009) Self-Concern, Self-Transcendence and Well-Being, European Sociological Review, online access published June 5, 2009.

North, D.C. (1990) Institutions, Institutional Change and Economic Performance. Cambridge UK: Cambridge University Press.

Pedersen, T. and Petersen, B. (1998) Explaining Gradually Increasing Resource Commitment to a Foreign Market, International Business Review, 7/5, 483-501.

Peng, M. W. (2002) Cultures, Institutions, and Strategic Choices: Toward an Institutional Perspective on Business Strategy, in M. Gannon and K. (eds.), The Blackwell Handbook of Cross-Cultural Management. Oxford: Blackwell, 52-66.

Podsakoff, P. \& Organ, D. (1986) Self-Reports in Organizational Research: Problem and Prospects, Journal of Management, 12/4, 531-544.

Pothukuchi, V.K., Damanpur, F., Choi, J., Chen, C. and Park, S.H. (2002) National and Organizational Culture Differences and International Joint Venture Performance, Journal of International Business Studies, 33/2, 243-265.

Ralston, D.A., Egri, C.P., Stewart, S., Terpstra, R.H., and Yu, K. (1999) Doing Business in the 21st Century with the New Generation of Chinese Manager: a Study of Generational Shifts in Work Values in China, Journal of International Business Studies, 30/3, 415-28.

Ramaprasad, A. and Stone, W.G. (1992) The Temporal Dimension of Strategy, Time and Society, 1/3, 35-377.

Salter, S. and Niswander, F. 1995. Cultural Influence on the Development of Accounting Systems Internationally, Journal of International Business Studies, 26/2, 379-397.

Schneider, S.C. and Barsoux, J.-L. (2002) Managing Across Cultures. London. FT/Prentice Hall.

Schoemaker, P. J.H. (1993) Multiple Scenario Developing: Its Conceptual and Behavioral Basis, Strategic Management Journal, 14/3, 193-213.

Sirmon, D.G. and Lane, P.J.A (2004) Model of Cultural Differences and International Alliance Performance. Journal of International Business Studies, 35/3, 306-319.

Tang, L. and Koveos, P.E. (2008) A Framework to Update Hofstede’s Cultural Value Indices: Economic Dynamics and Institutional Stability, Journal of International Business Studies, 39/6, 1045-1063. 
Thomas, L.G. and Waring, G. (1999) Competing Capitalisms: Capital Investment in American, German and Japanese Firms. Strategic Management Journal, 20/8, 729-748.

Tihanyi, L., Griffith, D.A. and Russell, C.J. (2005) The Effect of Cultural Distance on Entry Mode Choice, International Diversification, and MNE Performance: A MetaAnalysis, Journal of International Business Studies, 36/3, 270-283.

Triandis, H.C. (2004) The Many Dimensions of Culture, Academy of Management Executive, 18/1, 88-93.

Trompenaars, F. and Hampden-Turner, C. (1997) Riding the Waves of Culture:

Understanding Cultural Diversity in Business, London: Nicholas Brealey Publishing.

Wang, Z. (1998) Japanese Corporations' Investment in China, Beijing: Chinese Economic Press.

Table 1: Enterprise Strategies

\begin{tabular}{|l|l|l|}
\hline & SHORT-TERM STRATEGIES & LONG-TERM STRATEGIES \\
\hline Human Resource Strategies & Hire-and-fire & $\begin{array}{l}\text { Permanent contracts } \\
\text { Long-term contracts }\end{array}$ \\
\hline
\end{tabular}




\begin{tabular}{|l|l|l|}
\hline & Out-sourcing & Pension provision \\
\cline { 2 - 3 } & Piece-rates, short-term bonus & $\begin{array}{l}\text { Profit-sharing, employee shares } \\
\text { and options }\end{array}$ \\
\hline Investment Strategies & $\begin{array}{l}\text { High current stocks of materials, } \\
\text { products and financial assets (e.g. } \\
\text { bank cash) as a of sales }\end{array}$ & $\begin{array}{l}\text { High investment in fixed assets as } \\
\text { a of sales }\end{array}$ \\
\cline { 2 - 3 } & $\begin{array}{l}\text { Finance through short-term } \\
\text { borrowing }\end{array}$ & Finance through equity issue \\
\cline { 2 - 3 } & $\begin{array}{l}\text { Low levels of R\&D } \\
\text { spending/sales }\end{array}$ & $\begin{array}{l}\text { High levels of R } \\
\text { spending/sales }\end{array}$ \\
\cline { 2 - 3 } & Mergers and acquisitions & Organic firm growth \\
\hline R\&D Strategies & R\&D at home-country HQ & Local R\&D in China \\
\hline
\end{tabular}

Note: authors' own Table

Table 2: Nationality of JV Partner and Strategies

\begin{tabular}{|c|c|c|c|c|}
\hline Influence on JV & \multicolumn{3}{|c|}{ Nationality of JV Partner in PRC JV } \\
\cline { 2 - 5 } Strategies from: & $\begin{array}{c}\text { (1) Mainland } \\
\text { Chinese }\end{array}$ & $\begin{array}{c}\text { (2) Overseas } \\
\text { Chinese }\end{array}$ & (3) Other Asian & (4) Western \\
\hline $\begin{array}{c}\text { (1) Home } \\
\text { Country } \\
\text { Institutions }\end{array}$ & $\sqrt{ }$ & $\mathrm{X}$ & $\mathrm{X}$ & $\mathrm{X}$ \\
\hline $\begin{array}{c}\text { (2) Home } \\
\text { Country } \\
\text { Culture }\end{array}$ & $\sqrt{ }$ & $\sqrt{ }$ & $\sqrt{ }$ \\
\hline
\end{tabular}

Note: authors' own Table 
Table 3: Descriptive statistics and correlation matrix

\begin{tabular}{|c|c|c|c|c|c|c|c|c|c|c|c|c|c|c|c|c|c|c|}
\hline & Mean & $\begin{array}{l}\text { Std } \\
\text { Dev }\end{array}$ & 1 & 2 & 3 & 4 & 5 & 6 & 7 & 8 & 9 & 10 & 11 & 12 & 13 & 14 & 15 & 16 \\
\hline 1 HRM1 & 2.97 & 0.99 & 1.000 & & & & & & & & & & & & & & & \\
\hline 2 HRM2 & 3.53 & 1.64 & 0.690 & 1.000 & & & & & & & & & & & & & & \\
\hline 3 HRM3 & 4.085 & 1.25 & 0.302 & 0.217 & 1.000 & & & & & & & & & & & & & \\
\hline 4 Investment & 3.076 & 1.154 & -0.123 & -0.080 & 0.057 & 1.000 & & & & & & & & & & & & \\
\hline 5 Equity shares & 0.286 & 0.339 & -0.091 & -0.096 & -0.265 & 0.128 & 1.000 & & & & & & & & & & & \\
\hline 6 R\&D1 & 3.709 & 1.489 & 0.039 & 0.059 & 0.249 & 0.245 & -0.056 & 1.000 & & & & & & & & & & \\
\hline 7 R\&D2 & 4.339 & 1.471 & 0.048 & 0.011 & 0.201 & 0.083 & -0.066 & 0.658 & 1.000 & & & & & & & & & \\
\hline $\begin{array}{l}8 \text { Foreign Senior } \\
\text { Managers }\end{array}$ & 3.231 & 5.590 & -0.033 & -0.001 & -0.074 & 0.068 & 0.105 & 0.115 & 0.027 & 1.000 & & & & & & & & \\
\hline $\begin{array}{l}9 \text { Chinese } \\
\text { Senior managers }\end{array}$ & 5.187 & 6.507 & 0.037 & 0.087 & 0.070 & 0.110 & 0.163 & 0.086 & 0.090 & -0.585 & 1.000 & & & & & & & \\
\hline $\begin{array}{l}10 \text { US-European } \\
\text { and Chinese IJV }\end{array}$ & 0.329 & 0.471 & -0.177 & -0.117 & -0.069 & 0.024 & 0.065 & 0.083 & 0.102 & 0.076 & 0.154 & 1.000 & & & & & & \\
\hline $\begin{array}{l}11 \text { Japan- } \\
\text { Korean and } \\
\text { Chinese IJV }\end{array}$ & 0.334 & 0.476 & 0.054 & 0.003 & -0.071 & -0.071 & 0.005 & -0.139 & -0.059 & 0.105 & -0.003 & -0.508 & 1.000 & & & & & \\
\hline $\begin{array}{l}12 \text { HK-Taiwan } \\
\text { and Chinese IJV }\end{array}$ & 0.326 & 0.469 & 0.122 & 0.115 & 0.141 & 0.048 & -0.070 & 0.059 & -0.043 & -0.182 & -0.151 & -0.487 & -0.505 & 1.000 & & & & \\
\hline 13 AGE & 8.851 & 5.913 & 0.558 & 0.490 & 0.159 & -0.029 & -0.058 & 0.018 & -0.044 & 0.127 & 0.198 & 0.009 & 0.004 & -0.013 & 1.000 & & & \\
\hline 14 Size & 4.696 & 1.306 & 0.187 & 0.171 & 0.035 & -0.015 & 0.139 & 0.023 & -0.027 & 0.494 & 0.519 & 0.033 & 0.128 & -0.163 & 0.316 & 1.000 & & \\
\hline 15 Tianjin & 0.301 & 0.459 & -0.044 & -0.020 & 0.076 & 0.358 & -0.278 & -0.071 & -0.224 & 0.001 & 0.092 & -0.033 & 0.003 & 0.029 & 0.101 & -0.084 & 1.000 & \\
\hline 16 Qingdao & 0.161 & 0.368 & -0.039 & -0.053 & -0.387 & -0.103 & 0.387 & -0.209 & -0.140 & 0.027 & 0.035 & -0.106 & 0.134 & -0.030 & -0.168 & 0.015 & -0.288 & 1.000 \\
\hline
\end{tabular}

Notes: HRM1, HRM2 and HRM3 represent the variables of HRM strategies which were measured by employees’ tenure, the percentage of employees’ contracts for 5 years and employees’ pension, respectively. R\&D1 and R\&D2 stand for R\&D strategies, which were measured by the ratio of R\&D spending to sales and the percentage of IJVs’ R\&D contributed by parent companies. 
Table 4: Human Resource Management Strategies

\begin{tabular}{|c|c|c|c|c|c|c|c|c|c|}
\hline \multirow{2}{*}{\begin{tabular}{l}
\multicolumn{1}{|c}{ Independent Variables } \\
$\begin{array}{l}\text { Number of foreign senior } \\
\text { managers }\end{array}$
\end{tabular}} & \multicolumn{3}{|c|}{$\begin{array}{c}\begin{array}{c}\text { Dependent variable: } \\
\text { employees' tenure. } \\
\text { Ordered Probit }\end{array} \\
\end{array}$} & \multicolumn{3}{|c|}{$\begin{array}{c}\text { Dependent variable: } \\
\text { \% of Employees' contracts for } 5 \text { years. } \\
\text { Ordered Probit } \\
\end{array}$} & \multicolumn{3}{|c|}{$\begin{array}{c}\text { Dependent variable: } \\
\text { employees’ pension. } \\
\text { Ordered Probit }\end{array}$} \\
\hline & $\begin{array}{c}-.057 \\
(.014)^{* * *}\end{array}$ & $\begin{array}{c}.018 \\
(.020)\end{array}$ & $\begin{array}{c}.039 \\
(.046)\end{array}$ & $\begin{array}{c}-.024 \\
(.012)^{* * *}\end{array}$ & $\begin{array}{l}.011 \\
(.022)\end{array}$ & $\begin{array}{c}.019 \\
(.012)\end{array}$ & $\begin{array}{c}-.045 \\
(.014)^{* * *}\end{array}$ & $\begin{array}{c}.009 \\
(.021)\end{array}$ & $\begin{array}{l}.001 \\
.011\end{array}$ \\
\hline $\begin{array}{l}\text { Number of Chinese senior } \\
\text { managers } \\
\text { US-European and Chinese } \\
\text { IJV } \\
\text { Japan-Korean and Chinese } \\
\text { IJV } \\
\text { HK-Taiwan and Chinese } \\
\text { IJV }\end{array}$ & $\begin{array}{c}012 \\
(.007)^{* *} \\
-.289 \\
(.145)^{* * *}\end{array}$ & $\begin{array}{c}.237 \\
(.151) \dagger\end{array}$ & $\begin{array}{c}.537 \\
(.155)^{* * *}\end{array}$ & $\begin{array}{c}.002 \\
(.008) \\
-.379 \\
(.145)^{* * *}\end{array}$ & $\begin{array}{l}.015 \\
(.166)\end{array}$ & $\begin{array}{c}.298 \\
(.143)^{* *}\end{array}$ & $\begin{array}{l}.022 \\
(.006)^{* * *} \\
-.129 \\
(.154)\end{array}$ & $\begin{array}{c}.020 \\
(.008) * * *\end{array}$ & $\begin{array}{c}.507 \\
(.148)^{* * *}\end{array}$ \\
\hline \multicolumn{10}{|l|}{ Control variables } \\
\hline Age & $\begin{array}{c}.120 \\
(.008)^{* * *}\end{array}$ & $\begin{array}{c}.157 \\
(.013)^{* * *}\end{array}$ & $\begin{array}{c}.159 \\
(.013)^{* * *}\end{array}$ & $\begin{array}{c}.109 \\
(.013)^{* * *}\end{array}$ & $\begin{array}{c}.106 \\
(.012)^{* * *}\end{array}$ & $\begin{array}{l}.108 \\
.013\end{array}$ & $\begin{array}{l}.019 \\
(.012)\end{array}$ & $\begin{array}{l}.018 \\
(.012)\end{array}$ & $\begin{array}{c}.018 \\
(.012)\end{array}$ \\
\hline Size & $\begin{array}{c}.204 \\
(.033)^{* * *}\end{array}$ & $\begin{array}{c}.137 \\
(.036)^{* * *}\end{array}$ & $\begin{array}{c}.156 \\
(.035)^{* * *}\end{array}$ & $\begin{array}{c}.029 \\
(.035)\end{array}$ & $\begin{array}{c}.001 \\
(.033)\end{array}$ & $\begin{array}{l}-.011 \\
(.049)\end{array}$ & $\begin{array}{c}.246 \\
(.039)^{* * *}\end{array}$ & $\begin{array}{c}.197 \\
(.038)^{* * *}\end{array}$ & $\begin{array}{c}.234 \\
(.039)^{* *}\end{array}$ \\
\hline Tianjin & $\begin{array}{l}-.111 \\
(.135)\end{array}$ & $\begin{array}{c}-.261 \\
(.141) \dagger\end{array}$ & $\begin{array}{c}-.264 \\
(.140) \dagger\end{array}$ & $\begin{array}{l}-.246 \\
(.149)\end{array}$ & $\begin{array}{l}-.201 \\
(.148)\end{array}$ & $\begin{array}{l}-.247 \\
(.150)\end{array}$ & $\begin{array}{c}.016 \\
(.154)\end{array}$ & $\begin{array}{l}-.027 \\
(.153)\end{array}$ & $\begin{array}{l}.032 \\
(.153)\end{array}$ \\
\hline Qing Dao & $\begin{array}{l}.188 \\
(.178)\end{array}$ & $\begin{array}{l}.177 \\
(.180)\end{array}$ & $\begin{array}{l}.216 \\
(.178)\end{array}$ & $\begin{array}{l}-.067 \\
(.183)\end{array}$ & $\begin{array}{l}-.017 \\
(.183)\end{array}$ & $\begin{array}{l}-.036 \\
(.181)\end{array}$ & $\begin{array}{l}-.098 \\
(.183)\end{array}$ & $\begin{array}{l}-.082 \\
(.184)\end{array}$ & $\begin{array}{l}-.097 \\
(.185)\end{array}$ \\
\hline Indust & Included & Included & Included & Included & Included & Included & Included & Included & Included \\
\hline Observations & 316 & 316 & 316 & 316 & 316 & 316 & 316 & 316 & 316 \\
\hline
\end{tabular}

***, $* *, *, \dagger$ : significant at the $0.1 \%, 1 \%, 5 \%$ and $10 \%$ levels respectively. 
Table 5: Investment Strategies

\begin{tabular}{|c|c|c|c|c|c|c|}
\hline \multirow{3}{*}{\begin{tabular}{l}
\multicolumn{1}{c}{$\begin{array}{c}\text { Independent } \\
\text { Variables }\end{array}$} \\
$\begin{array}{l}\text { Number of foreign } \\
\text { senior managers }\end{array}$
\end{tabular}} & \multicolumn{3}{|c|}{$\begin{array}{c}\text { Dependent variable: } \\
\text { Annual average value of investment in } \\
\text { fixed assets as a \% of sales. } \\
\text { Tobit model }\end{array}$} & \multicolumn{3}{|c|}{$\begin{array}{l}\text { Dependent variable: } \\
\text { Average value of (long term) equity shares as a } \\
\% \text { of total capital. } \\
\text { Tobit model }\end{array}$} \\
\hline & -.002 & .011 & .008 & 008 & .004 & .007 \\
\hline & $(.014)$ & $(.019)$ & $(.012)$ & $(.006)$ & $(.007)$ & $(.005)$ \\
\hline Number of Chinese & 039 & .039 & .037 & .017 & .017 & .016 \\
\hline senior managers & $(.007) * * *$ & $(.007) * * *$ & $(.007) * * *$ & $(.006) * * *$ & $(.006)^{* * *}$ & $(.005) * * *$ \\
\hline US-European and & .051 & & & -.006 & & \\
\hline Chinese IJV & $(.142)$ & & & $(.009)$ & & \\
\hline Japan-Korean and & & -.097 & & & -.002 & \\
\hline Chinese IJV & & $(.147)$ & & & $(.009)$ & \\
\hline HK-Taiwan and & & & .216 & & & -.018 \\
\hline Chinese IJV & & & $(.134)^{* *}$ & & & $(.067)$ \\
\hline \multicolumn{7}{|l|}{ Control variables } \\
\hline \multirow[t]{2}{*}{ Age } & -.017 & -.017 & -.017 & -.006 & -.005 & -.006 \\
\hline & $(.011)$ & $(.011)$ & $(.011)$ & $(.006)$ & $(.006)$ & $(.007)$ \\
\hline \multirow[t]{2}{*}{ Size } & .243 & .242 & .237 & .003 & .006 & .001 \\
\hline & $(.034) * * *$ & $(.036) * * *$ &.$(035) * * *$ & (.019) & $(.019)$ & $(.019)$ \\
\hline \multirow[t]{2}{*}{ Tianjin } & 1.049 & 1.061 & 1.038 & -.326 & -.323 & -.324 \\
\hline & $(.138)^{* *}$ & $(.139)^{* * *}$ & $(.138)^{* *}$ & $(.074) * * *$ & $(.075) * * *$ & $(.075) * * *$ \\
\hline \multirow[t]{2}{*}{ Qing Dao } & .293 & .303 & .281 & .431 & .425 & .429 \\
\hline & $(.177)$ & $(.178)$ & $(.176)$ & $(.082)^{*}$ & $(.083) \dagger$ & $(.082) \dagger$ \\
\hline Industry dummy & Included & Included & Included & Included & Included & Included \\
\hline Observations & 316 & 316 & 316 & 316 & 316 & 316 \\
\hline
\end{tabular}


Table 6: R\&D Investment Strategies

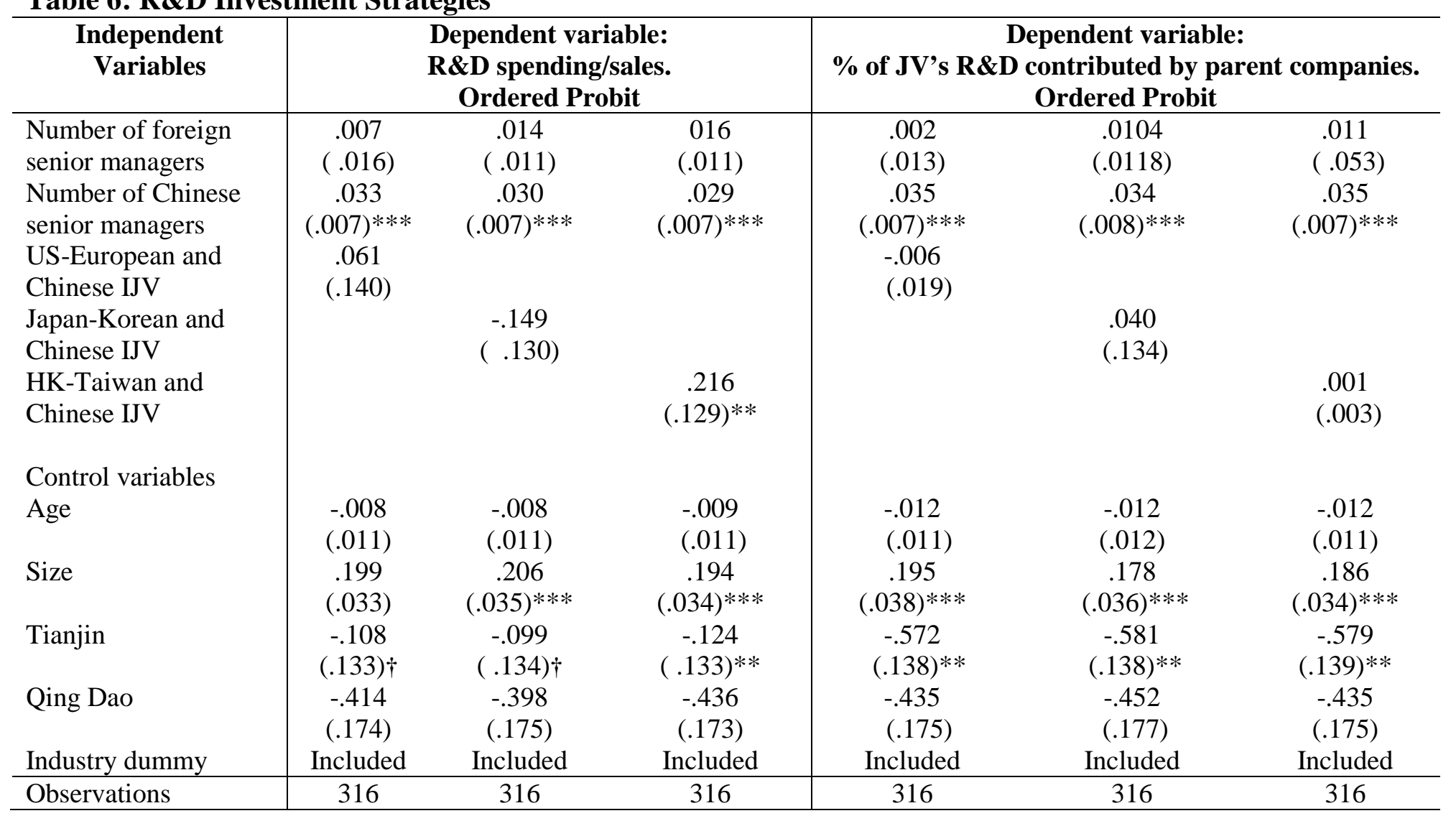


Appendix: A Survey of Foreign Equity JVs in High-Tech industry in Beijing, Tianjin and Qingdao

Section A

A1. Current ownership stakes in JV by nationality?

A2. Current stakes in control of JV (seats on Board) by nationality?

A3. How many employees does the company have currently?

A4. How many years has the company been established?

\section{Section B}

The following questions refer to averages over the eight years 1998-2005 unless otherwise stated

\section{Human Resource Strategies:}

B11 Average employee's tenure with the firm?

B12 Percentage of permanent staff in your company?

B13 Average contribution of JV to employees’ pension fund (as a \% of total pay)?

\section{Investment Strategies}

B21. Annual average value of investment by the JV in fixed assets as a \% of sales?

B22. The percentage of equity in long term capital?

\section{R\&D Strategies}

B31. Average value of JV's R\&D spending as a \% of sales in last seven years?

B32. \% of R\&D carried out in Chinese JV?

B33. \% of JV's R\&D carried out in main foreign partner? 